\title{
Observations on the Utility of the Semi-directive Interview for Documenting Traditional Ecological Knowledge
}

\author{
HENRY P. HUNTINGTON ${ }^{1}$
}

\author{
(Received 9 August 1997; accepted in revised form 16 December 1997)
}

\begin{abstract}
Traditional ecological knowledge(TEK) offers ecological information and insight relevant to ecological management and research that cannot be obtained from other sources. Its use is hindered by difficulties of access, in that TEK is typically not available to a wide audience. Documentation can overcome this obstacle, allowing TEK to be considered with other forms of easily disseminated information. This paper describes the author's experience using the semi-directive interview to document TEK about beluga whales in Alaska. This method allows the participants as well as the researcher to guide the interview, so that associations made by the participant, and not just those anticipated by the researcher, are discussed. Using maps as the starting point for discussions with individuals or groups, the interviews covered expected topics, such as migration and feeding behavior, as well as unanticipated topics, such as the possible influence of beavers on beluga distribution. The primary research session was followed a year later by a review session to verify the accuracy of the draft report, add missing information, or remove information the publication of which might harm community interests. The author found the semi-directive interview to be an effective and powerful method for accurate and comprehensive documentation of TEK. It worked especially well in group interviews, which allowed participants to stimulate and validate each other.
\end{abstract}

Key words: traditional ecological knowledge, TEK, semi-directive interview, documentation, beluga, Delphinapterus leucas

RÉSUMÉ. Le savoir écologique traditionnel (SET) offre de l'information écologique et une opinion pertinente à la gestion et à la recherche écologiques qu'on ne peut obtenir d'autres sources. Un accès difficile gêne l'utilisation du SET, vu qu'en général il n'est pas disponible à un vaste public. On peut surmonter cet obstacle en créant de la documentation, ce qui permet de tenir compte du SET parallèlement à d'autres formes d'information facilement diffusée. Cet article décrit l'expérience de l'auteur qui s'est servi de l'interview semi-dirigée pour documenter le SET sur les bélougas de l'Alaska. Cette méthode permet aux participants autant qu'au chercheur de guider l'interview, de sorte que les associations faites par le participant, et pas uniquement celles anticipées par le chercheur, sont discutées. Des cartes servant à démarrer la discussion avec des individus ou des groupes, les interviews couvraient des sujets prévus comme la migration et le comportement alimentaire, en même temps que des sujets imprévus, comme l'influence possible des castors sur la distribution du bélouga. La recherche primaire était suivie un an plus tard d'une session de récapitulation afin de vérifier l'exactitude de l'ébauche du rapport et d'ajouter de l'information manquante, ou d'éliminer de l'information dont la publication aurait pu nuire aux intérêts de la collectivité. L'auteur a trouvé que l'interview semi-dirigée était une méthode efficace et puissante pour documenter le SET de façon précise et détaillée. Elle fonctionnait particulièrement bien dans les entrevues en groupes, qui offraient aux participants la possibilité d'échanges stimulants et de validation mutuelle.

Mots clés: savoir écologique traditionnel, SET, interview semi-dirigée, documentation, bélouga, Delphinapterus leucas

Traduit pour la revue Arctic par Nésida Loyer.

\section{INTRODUCTION}

In recent years, interest in traditional ecological knowledge (TEK) has been increasing. Many factors have contributed to this increase. These include a recognition of the value of perspectives other than the scientific, the assertion of and consequent political recognition of indigenous rights, a growing body of research on TEK both in the Arctic and elsewhere, collaboration by indigenous groups in international fora to promote the use of TEK, and the increase in cooperative development and management strategies to which TEK can contribute (Brokensha et al., 1980; Huntington, 1992; Johnson, 1992; Brooke, 1993; Inglis, 1993; Johannes, 1993; Mailhot, 1993; Thomsen, 1993; Johnson and Ruttan, 1993; DeWalt, 1994; Hansen, 1994; Agrawal, 1995; Kawagley, 1995; Fehr and Hurst, 1996; Tennberg, 1996; Caulfield, 1997; Kalxdorff, 1997; McDonald et al., 1997).

TEK is the system of experiential knowledge gained by continual observation and transmitted among members of a community. It is set in a framework that encompasses both ecology and the interactions of humans and their

\footnotetext{
${ }^{1}$ Inuit Circumpolar Conference, 401 East Northern Lights Blvd., Suite 203, Anchorage, Alaska 99503, U.S.A.; present address:

Huntington Consulting, P.O. Box 773564, Eagle River, Alaska 99577, U.S.A.; hph@alaska.net

(C) The Arctic Institute of North America
} 


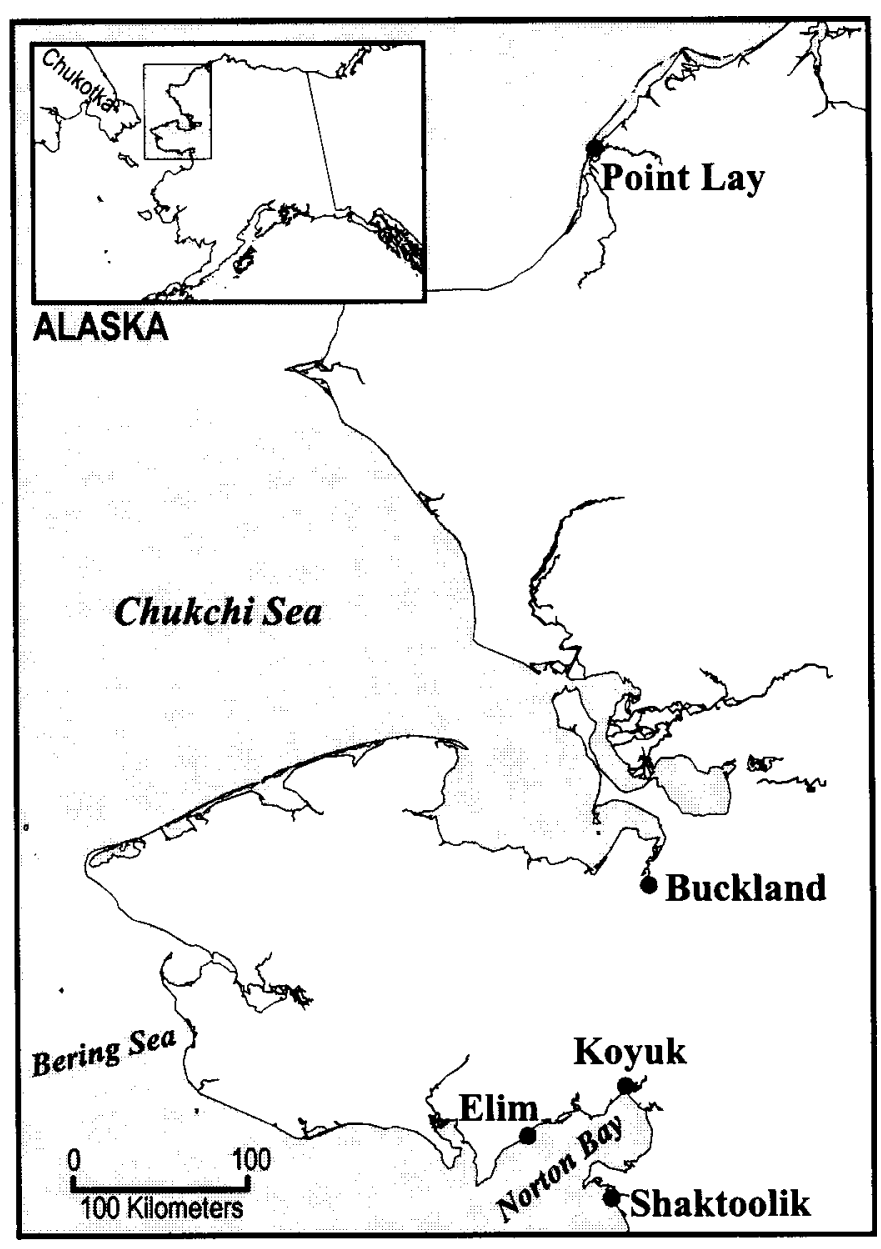

FIG. 1. Northwestern Alaska and the communities involved in the study.

environment on physical and spiritual planes. Proponents of TEK argue that its ecological information and insights must be used in addition to other sources of information if environmental and wildlife management strategies are to be effective in both biological and cultural terms (Huntington, 1992; Stevenson, 1996). Furthermore, the contribution of TEK is a means by which resource users can gain a role in developing and implementing such strategies (Huntington, 1992; Agrawal, 1995).

The use of TEK is often hindered because it is unavailable to or considered irrelevant by a broad audience. In the absence of wide access, the influence of TEK extends only as far as the influence of those who hold it. Holders of TEK may be able to speak, and speak forcefully, at public hearings and in other fora, but the undocumented information is not portable, and the influence of such spoken testimony diminishes with distance in time and space. Documentation is one means by which TEK can be made more accessible, allowing it to be considered in parallel with other information, typically from scientific studies, that is written.

The problem, therefore, is to identify a feasible way to document TEK accurately. The difficulties of doing so include those of cross-cultural communication and understanding, as well as recognition of the uncertainties inherent in any ecological description (Briggs, 1986; Johnson, 1992; Johnson and Ruttan, 1993; Fehr and Hurst, 1996; Ferguson and Messier, 1997). In addition, it is difficult for a questionnaire or survey to either anticipate or easily access the scope of knowledge incorporated in TEK.

The semi-directive interview is a standard ethnographic method for gathering information in an open-ended format (Briggs, 1986). Both this method and related techniques have been successfully used in the context of TEK research (Johnson, 1992; Brooke, 1993; Johnson and Ruttan, 1993; Ferguson and Messier, 1997). Ethnographic research has also long employed maps as a stimulus for discussion and a means of documenting data for, among other uses, land claims (Freeman, 1976; Nahanni, 1977; Cruikshank, 1981). This paper describes in detail the application of the semi-directive interview method to a project on beluga whales (Delphinapterus leucas) and assesses its utility for documenting TEK (see Johnson and Ruttan [1993] and Ferguson and Messier [1997] for other discussions of documenting TEK).

The purpose of this study was to use the semi-directive interview to document TEK about beluga whales. I conducted the research in northern and western Alaska, and collaborated with Nikolai Mymrin on the research in Chukotka, Russia (Huntington and Mymrin, 1996). One objective of the research was to assess the utility of the semi-directive interview for documenting TEK. For this paper, I concentrate on the fieldwork conducted in Alaska. The participants in the interviews were Iñupiaq and Yupik hunters and elders from the communities of Buckland, Elim, Koyuk, Point Lay, and Shaktoolik (Fig. 1).

\section{USING THE SEMI-DIRECTIVE INTERVIEW: TEK OF BELUGA WHALES}

In the semi-directive interview (Nakashima and Murray, 1988; Nakashima, 1990), the participant or participants are guided in the discussions by the interviewer, but the direction and scope of the interview are allowed to follow the associations identified by the participant. There is no fixed questionnaire, nor is there a preset limit on the time for discussions, although a list of topics may be a useful reference, helping the interviewer cover important areas while allowing the participants to add or skip topics depending on their interest and expertise.

I conducted the beluga study in Point Lay, Buckland, and Norton Bay, Alaska. (The three villages of Elim, Koyuk, and Shaktoolik in Norton Bay were studied together.) In initial consultations with the communities, I obtained permission from the village councils to conduct the study. This permission allowed me to gather information and to compile and publish a report and other documents based on that information. The raw data belong to the community, and their further use, by me or by other researchers, requires consent of the community. The materials - maps, tape recordings, and notebooks - are to be stored in a place agreed upon by the community and the researcher. 
In the first round of fieldwork, I interviewed participants in each community during the course of a week's stay in the village. In Point Lay and Buckland, I conducted individual interviews with a total of 14 participants. The interviews lasted from 45 minutes to two hours, and in some cases a second interview was held, for a total interview time of up to four hours with a participant. Following the interviews, I compiled the information on one set of maps. Before leaving the village, I reviewed with the participants a summary of what I had learned in the interviews. These initial reviews allowed me to check my understanding of the information gathered and to let the participants know what information I was taking with me.

In Norton Bay, I conducted group interviews with nine participants over successive days, again followed with a review session of the compiled information. These sessions lasted all day; allowing for breaks, the total interview time each day was typically five hours or so. In all communities, the participants were compensated for their time, and for time spent later in reviewing the draft report and discussing it in the review sessions held the following winter and spring.

During the interviews, I used a map of the area with a mylar overlay, on which place names, areas associated with certain behaviors, paths and directions associated with migratory and other movements, bathymetry, and other information were recorded. The map was an invaluable aid to the interview, since the depiction of the physical world provided a common reference point. Although not all aspects of beluga ecology are mappable, I believe that the depth of detail given even to behavior and other nonspatial information was in large part a result of beginning with a tangible reference.

In Buckland and Norton Bay, I hired a village assistant to help arrange interviews, take notes, and steer the interview. (In Point Lay, I was unable to find someone to do this task; instead, the village mayor helped make introductions.) The assistant was a valuable addition. He or she identified local place names and terminology, prompted discussion of topics of which I, as an outsider, was unaware, and seemed to make the conversation easier for some participants by placing the interview in a more familiar social context. Since the semidirective interview is closer to Iñupiaq and Yupik ways of discussion than a fixed questionnaire, the assistants required little additional training beyond an introduction to the project, its objectives, and a summary of the method.

The interviews were conducted in English, with the exception of some portions of the group interviews in Norton Bay. Most participants were comfortable speaking and reading English, which is perhaps more prevalent in Alaska than in Inuit regions of Canada (Huntington, in press). In the Norton Bay group interviews, the eldest participant was not comfortable speaking English. Other members of the group would translate for him, and occasionally hold conversations in Iñupiaq on a particular point, summarizing the information for me afterwards. Since two of the other participants were bilingual teachers, the accuracy of translation was not considered a problem.
Conversations in English in these communities often include Iñupiaq words as well as local idioms (Nageak, 1991). Past experience working with Iñupiaq and Yupik hunters and whalers helped me understand these particular usages, and the village assistant was a further help. In most cases of uncertainty, the participants were able to give a clear explanation in response to my repeated and rephrased questions.

Following the interviews, I compiled a draft report with maps, and circulated this to each participant and also to the village councils for review. Because the information collected covers a wide range of topics, some more closely related to beluga ecology than others, I presented the information from each village or area, arranged by topic, without interpretation or analysis. I viewed my task as that of compiler and editor rather than author. The final report is divided in sections according to topics, such as migration, feeding, and changes over time. Each section describes various aspects of its topic as described by the participants, but without an attempt by me to place them in a framework beyond that provided by the participants. The result, in places at least, is more a series of observations than an integrated and sustained narrative.

Shortly after this draft report was sent to each participant for review, I visited the village to discuss any necessary additions, deletions, or corrections. In the review sessions I had with each participant or group, we reviewed the maps and the text and discussed both the presentation and the accuracy of the information. Most participants had read the draft and had comments or suggestions for changes. For the most part, only relatively minor changes were needed. In Norton Bay, the participants decided to omit certain details of fish locations (i.e., beluga prey), because of concerns that their competitors in commercial fishing might take advantage of the information. Such an event had occurred previously with regard to herring (Clupea pallasi). In accordance with my research agreements with the village councils and with the participants, I replaced the detailed description with a note explaining the omission.

Following the reviews, I completed the final maps and text, and had the report printed and sent to the participants, the village councils, and others who were interested. A trilingual version of the report, in English, Iñupiaq, and Yupik, was also prepared and sent to the participants and their communities. Subsequently, I prepared manuscripts to submit to appropriate journals to publish the information provided by the participants.

\section{KEY RESULTS}

The interviews yielded overall descriptions of migratory patterns, local movements, feeding behavior and prey patterns, predator avoidance, calving, bathymetry, ecological interactions, human influences, and other information (Huntington and Mymrin, 1996). Broadly, the descriptions are in accordance with current scientific understanding, though the overlap is not complete. While scientific research 
has examined migratory patterns, stock identities, and some aspects of local behavior (e.g., Frost and Lowry, 1990; Frost et al., 1993), TEK provides more specific details. In addition, TEK describes aspects of interactions with humans and anthropogenic influences, such as noise, that are rare in the published scientific descriptions of belugas.

Of particular interest was the way that the semi-directive method allowed the discussions to flow according to the associations made by the participants rather than those that might have been anticipated by the interviewer. As one example, during the group interviews in Norton Bay, the conversation moved from the bay itself to rivers and to beaver (Castor canadensis). I, as interviewer, was thinking about a tactful way to exercise the "directive" half of the methodology and at least steer the conversation back to saltwater, when one of the elders enlightened me as to the relevance of beaver. The beaver population is increasing, and beavers dam streams where certain anadromous fish species spawn, affecting the abundance and distribution of the fish, and thus the patterns and behavior of the belugas that feed on them. Had I planned a questionnaire, I would not have thought to include a question about beavers.

\section{DISCUSSION}

The semi-directive interviews produced informative, wide-ranging discussions about belugas, the nearshore ecosystem, and human interactions with belugas and other harvested species. While I had initially planned to hold group interviews in all three locations, the participants' involvement in other activities meant that in Buckland and Point Lay I was able to hold only individual interviews with, as noted above, group review sessions at the end of my week in the village. While the interactions between the participants in the group interviews in Norton Bay convinced me that this is the preferred technique where possible, the individual interviews were nonetheless a good alternative.

In the group interview, the participants were able to encourage each other to recall specific events, to spur each other's memories, and to discuss the details of a particular item in order to arrive at a consensus based on their knowledge of the area and of each other. This latter point is important: I place myself in an awkward position if, on the one hand, I attempt to present as faithfully as possible what the participants tell me about belugas, and, on the other, I try to assess the reliability of each informant in comparison with the others. Such assessment by comparison becomes necessary when contradictory information is provided in separate interviews. The group review sessions were an opportunity to resolve these apparent conflicts, but did not allow for as detailed a discussion as was possible in the group interview when a similar situation arose.

The semi-directive interviews, as expected, produced a thorough description of the extent of TEK about belugas in the three areas. The technique allowed the participants to make connections that they saw and that might not be anticipated by an interviewer, as was the case with the impacts of beaver described above. The final report was regarded by the participants as an accurate and thorough compilation of what they know about belugas. A biologist familiar with the areas regarded the TEK documented in the final report as consistent and complete in comparison with the information she has learned from the hunters and elders over many years (K. Frost, pers. comm. 1996).

In the cross-cultural setting in which the beluga study was conducted, the semi-directive interviews provided the flexibility needed to adjust the interview to meet the characteristics of each interaction between interviewer and participant. Ideally, the interview would become more of a discussion or conversation, resembling in some ways the typical discussions that hunters and elders would have among themselves on similar topics. In this sense, the group interviews were useful in that the interviewer at times could become an observer, letting the discussion flow without any intervention.

What the semi-directive interview fails to do, at least in the way I conducted it, is to answer specific questions that a researcher might have in advance. While I prompted the participants on general topics, such as migration, calving, and feeding, I did not ask detailed questions on subjects in which I had a particular interest. Such a modification might be relatively simple to make, if a researcher wanted to cover a particular aspect of beluga ecology, by adding specific but open-ended questions. Asking questions that require only a simple answer, or that do not leave room for further observations by the participant, would stifle the extended discussions that proved so productive in the semi-directive interviews I conducted. Similarly, in a questionnaire, leaving only a final question such as "Is there anything else you would like to add?" is not an adequate substitute for developing throughout the interview a feeling of mutual involvement and interest in a conversation. The advantage of easily analyzed responses versus the opportunity for unanticipated insights must be weighed by the researcher.

While documentation is a useful and perhaps necessary first step, it neither analyzes its own data in comparison with data from other sources, nor-by itself-does documentation apply TEK to issues of management or research. While appropriate research designs can and should anticipate the uses to which the information will be put, these steps require other mechanisms to involve the holders of TEK in the fora where analysis and application take place. There is great interest in many areas in co-management as a mechanism for bringing hunters and their knowledge to these stages of research and management (Pinkerton, 1989; Huntington, 1992; Stevens, 1997). The Alaska Beluga Whale Committee (Adams et al., 1993) is an example of such a forum for discussing belugas, and it is here that the next steps must be taken to make use of TEK in the decisions that affect beluga hunters, biologists, and managers. 


\section{CONCLUSIONS}

The semi-directive interview is a powerful method for documenting TEK. It allows the interviewer to capture a wide range of information by directing discussions to the extent necessary to cover topics thoroughly and in detail. It also allows the participants in the interview to discuss and describe their understanding of the topics, and to make connections based on that understanding rather than on the questions drawn up in advance by the interviewer.

While documentation is an important first step, more work is needed on using TEK expertise in analyzing the information generated both in TEK and in biological studies, and in applying the results of documentation and analysis to problems of research and management.

\section{ACKNOWLEDGEMENTS}

The research from which this paper derives was funded by the National Science Foundation, the Trust for Mutual Understanding, the U.S. Fish and Wildlife Service, and the Department of Indian Affairs and Northern Development, Canada. I am grateful for their support and encouragement.

In addition, I thank the participants in the beluga study and those who helped make the study possible, as well as the following individuals: Nikolai I. Mymrin, Lorraine Brooke, William Kemp, Taylor Brelsford, Fred McFarland, Kathryn J. Frost, Jody Seitz, and Caleb Pungowiyi. Three anonymous reviewers suggested improvements to the original manuscript, for which I am grateful.

\section{REFERENCES}

ADAMS, M., FROST, K., and HARWOOD, L. 1993. Alaska and Inuvialuit Beluga Whale Committee (AIBWC) - An initiative in "at-home management." Arctic 46(2):134-137.

AGRAWAL, A. 1995. Dismantling the divide between indigenous and scientific knowledge. Development and Change 26(3): $413-439$.

BRIGGS, C.L. 1986. Learning how to ask: A sociolinguistic appraisal of the role of the interview in social science research. Cambridge: Cambridge University Press. 155 p.

BROKENSHA, D., WARREN, D.M., and WERNER, O. 1980. Indigenous knowledge systems and development. Lanham, Maryland: University Press of America.

BROOKE, L.F. 1993. The participation of indigenous peoples and the application of their environmental and ecological knowledge in the Arctic Environmental Protection Strategy. Vol. 1. Ottawa: Inuit Circumpolar Conference. 119 p.

CAULFIELD, R.A. 1997. Greenlanders, whales, and whaling: Sustainability and self-determination in the Arctic. Hanover, New Hampshire: University Press of New England. 203 p.

CRUIKSHANK, J. 1981. Legend and landscape: Convergence of oral and scientific traditions in the Yukon Territory. Arctic Anthropology 18(2):67-94.
DEWALT, B.R. 1994. Using indigenous knowledge to improve agriculture and natural resource management. Human Organization 53(2):123-131.

FEHR, A., and HURST, W. 1996. A seminar on two ways of knowing: Indigenous and scientific knowledge. Inuvik, Northwest Territories: Aurora Research Institute. 93 p.

FERGUSON, M.A.D., and MESSIER, F. 1997. Collection and analysis of traditional ecological knowledge about a population of arctic tundra caribou. Arctic 50(1):17-28.

FREEMAN, M.M.R., ed. 1976. Report of the Inuit land use and occupancy project. 3 vols. Ottawa: Indian and Northern Affairs Canada.

FROST, K.J., and LOWRY, L.F. 1990. Distribution, abundance, and movements of beluga whales, Delphinapterus leucas, in coastal waters of western Alaska. In: Smith, T.G., St. Aubin, D.J., and Geraci, J.R., eds. Advances in research on the beluga whale, Delphinapterus leucas. Canadian Bulletin of Fisheries and Aquatic Science 224. 39-57.

FROST, K.J., LOWRY, L.F., and CARROLL, G.M. 1993. Beluga whale and spotted seal use of a coastal lagoon system in the northeastern Chukchi Sea. Arctic 46(1):8-16.

HANSEN, B., ed. 1994. Report on the Seminar on Integration of Indigenous Peoples and Their Knowledge, Reykjavik, Iceland, September 1994. Copenhagen: Ministry for the Environment (Iceland), Ministry of the Environment (Denmark), and the Home Rule of Greenland (Denmark Office).

HUNTINGTON, H.P. 1992. Wildlife management and subsistence hunting in Alaska. London: Belhaven Press. 177 p.

- In press. Peoples of the Arctic: Characteristics of human populations relevant to pollution issues. In: Arctic Monitoring and Assessment Program. The AMAP assessment report: Arctic pollution issues. Oslo: Arctic Monitoring and Assessment Program.

HUNTINGTON, H.P., and MYMRIN, N.I. 1996. Traditional ecological knowledge of beluga whales: An indigenous knowledge pilot project in the Chukchi and northern Bering Seas. Anchorage, Alaska: Inuit Circumpolar Conference. 88 p.

INGLIS, J.T., ed. 1993. Traditional ecological knowledge: Concepts and cases. Ottawa: International Program on Traditional Ecological Knowledge and International Development Research Centre. 142 p.

JOHANNES, R.E. 1993. Integrating traditional ecological knowledge and management with environmental impact assessment. In: Inglis, J.T., ed. Traditional ecological knowledge: Concepts and cases. Ottawa: International Program on Traditional Ecological Knowledge and International Development Research Centre. 33-39.

JOHNSON, M., ed. 1992. Lore: Capturing traditional environmental knowledge. Ottawa: Dene Cultural Institute and International Development Research Centre. 190 p.

JOHNSON, M., and RUTTAN, R.A. 1993. Traditional Dene environmental knowledge: A pilot project conducted in Ft. Good Hope and Colville Lake NWT, 1989-1993. Hay River, Northwest Territories: Dene Cultural Institute. 309 p.

KALXDORFF, S.B. 1997. Collection of local knowledge regarding polar bear habitat use in Alaska. Technical Report MMM 97-2. Anchorage, Alaska: U.S. Fish and Wildlife Service. 55 p. 
KAWAGLEY, A.O. 1995. A Yupiaq worldview: A pathway to ecology and spirit. Prospect Heights, Illinois: Waveland Press. $166 \mathrm{p}$.

MAILHOT, J. 1993. Traditional ecological knowledge: The diversity of knowledge systems and their study. Great Whale Environmental Assessment: Background Paper No. 4. Montreal: Great Whale Public Review Support Office. 48 p.

McDONALD, M., ARRAGUTAINAQ, L., and NOVALINGA, Z. 1997. Voices from the bay: Traditional ecological knowledge of Inuit and Cree in the Hudson Bay bioregion. Ottawa: Canadian Arctic Resources Committee and Environmental Committee of the Municipality of Sanikiluaq. 90 p.

NAGEAK, J.M. 1991. An unusual whaling season: An interview with Waldo Bodfish, Sr. In: Bodfish, W., Sr. Kusiq. Fairbanks: University of Alaska. 237-246.

NAHANNI, P. 1977. The mapping project. In: Watkins, M., ed. Dene Nation-The colony within. Toronto: University of Toronto Press. 21-27.

NAKASHIMA, D.J. 1990. Application of native knowledge in EIA: Inuit, eiders, and Hudson Bay oil. Ottawa: Canadian Environmental Assessment Research Council.
NAKASHIMA, D.J., and MURRAY, D.J. 1988. The common eider (Somateria mollissima sedentaris) of eastern Hudson Bay: A survey of nest colonies and Inuit ecological knowledge. Report No. 102. Ottawa: Environmental Studies Revolving Fund.

PINKERTON, E., ed. 1989. Cooperative management of local fisheries. Vancouver: University of British Columbia. 299 p.

STEVENS, S., ed. 1997. Conservation through cultural survival: Indigenous peoples and protected areas. Washington, D.C.: Island Press. $361 \mathrm{p}$.

STEVENSON, M.G. 1996. Indigenous knowledge in environmental assessment. Arctic 49(3):278-291.

TENNBERG, M. 1996. Indigenous peoples' involvement in the Arctic Council. Northern Notes 4:21-32. Hanover, New Hampshire: Dartmouth College.

THOMSEN, M.L. 1993. Local knowledge of the distribution, biology, and hunting of beluga and narwhal: A survey among Inuit hunters in West and North Greenland. Nuuk: Greenland Hunters' and Fishermen's Association, Greenland Home Rule Authorities, and Inuit Circumpolar Conference. 